\title{
COMPARATIVE STUDY OF THE PRODUCTION OF CLOSED WATER FISHERY RESOURCES INSIDE AND OUTSIDE THE EMBANKMENT OF MEGHNA DHONAGODA IRRIGATION PROJECT
}

\author{
Md. Motaher Hossain*, Mohammed Shafi ${ }^{1}$, Md. Kawser Ahmed ${ }^{1}$ \\ and M. Niamul Naser ${ }^{2}$ \\ Department of Fisheries, Matshya Bhaban, Ramna, Dhaka, Bangladesh
}

\begin{abstract}
A comparative carried out was done on the closed water fishery resources between inside and outside the embankment of Meghna Dhonagoda Irrigation Project (MDIP). This research explores that the culture fishery has been developed inside the MDIP project area after the construction of Flood Control, Drainage and Irrigation (FCDI) Project. The average production of fishes in closed water (ponds and borrow pits) was higher inside $(2374.39 \mathrm{~kg} / \mathrm{ha}$ and 2436.37 $\mathrm{kg} / \mathrm{ha}$ ) than outside $(1984.32 \mathrm{~kg} / \mathrm{ha}$ and $2075.01 \mathrm{~kg} / \mathrm{ha})$ in $2003-2004$ and $2004-$ 2005. The significant difference $(\mathrm{p}<0.001)$ was found between the production of two zones. The overall production of closed water increased inside the embankment in all cases except culturable ponds. Production of culturable ponds was higher in outside due to the entrance of natural fish in inundated ponds during monsoon.

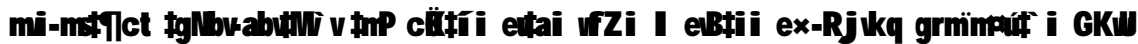

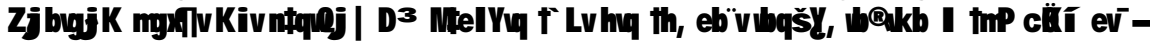

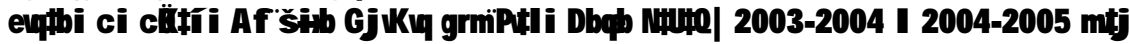

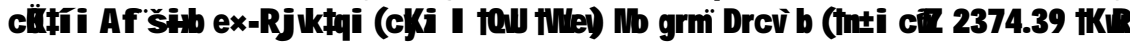

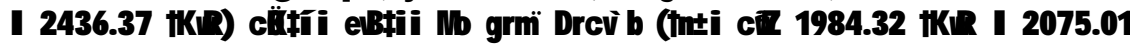

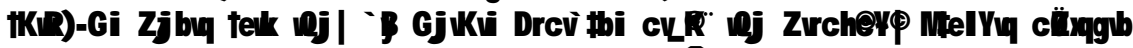

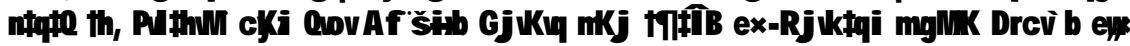

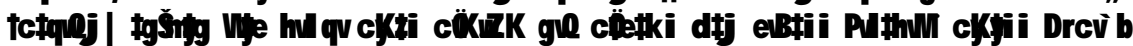
tevk טQj I

Key words: ponds, borrow pits, MDIP, fish, production, irrigation, embankment.
\end{abstract}

\section{INTRODUCTION}

Inland closed water fisheries resources are very rich in Bangladesh. Culture based fishery is the most suitable in closed water bodies mainly ponds and borrow pits in our country. After the construction of Flood Control, Drainage and Irrigation Projects, the culture fishery has been developed in the project areas. Fish production increased to 21.02 lakhs $\mathrm{mt}$ in 2003-2004, which was 17.81 lakhs $\mathrm{mt}$ in 2000-2001 (DOF 2005). In Bangladesh, fish provides up to $63 \%$ of animal proteins consumed (BBS 2001 and DOF 2005).

Fish as a staple article of food, must have found favourable to man at a very early stage of his history. The muscular tissue of flesh or a fish is made up of 60

*Corresponding author. ${ }^{1}$ Department of Fisheries, University of Dhaka, Dhaka-1000, Bangladesh. E-mail: kawser@univdhaka.edu 2Department of Zoology, University of Dhaka, Dhaka-1000, Bangladesh. 
to 82 percent water, about 13 to 20 percent proteins and a greater or lesser amount of fat (Qureshi 1951). So, like other rice eating people of the world, the Bangladeshi is very fond of fish. Every time they prefer fish to meat. Fish was literally available on the very doorstep of the people, fresh and often alive (Ahmad 1952).

At national level, $46 \%$ of the ponds are under aquaculture. The remaining ponds either culturable or derelicts (BFRSS 1986). SPARRSO (1984) estimated the area of derelict, cultured and culturable ponds to be about 43, 27 and 30\%, respectively but according to BFRSS (2004) these are 12, 65 and 23\%, respectively. In the year $1987-88$, total inland culture production was 1.76 tones, but in 2004-2005, the total inland culture production was $8.82 \mathrm{mt}$. out of which only pond production was $7.57 \mathrm{mt}$ (BFRSS 2005). Before the flood control and irrigation projects were implemented, the production of fishponds in floodprone areas was very low. Aquaculture was risky because there was the possibility of inundation. Once flood control infrastructure was built, this risk greatly diminished. According to recent statistics, $2482 \mathrm{~kg} / \mathrm{ha}$ is produced on an average in the ponds of Bangladesh (DOF 2005).

More than $80 \%$ of the animal protein in the diet comes from fisheries products alone (Rubbi et al. 1978). Most of the people in developing world are still dependent almost entirely on fish as a source of animal protein. Fish protein is $85-95 \%$ digestible and all dietary essential amino acids are present in fish (Nilson 1946).

In 1987, Bangladesh became third in world inland fish and shrimp production after China and India, and produced $581,827 \mathrm{mt}$ of fish and shrimp (FAO 1987). So, fisheries sector plays an important role regarding employment generation, animal protein supply, and foreign currency earning and poverty alleviation.

Although after the construction of embankment inland open water fisheries decreased, but pond production increased. Bangladesh has 1,288,222 manmade ponds which provide a total area of 146,890 ha (BFRSS 1986). At present, some borrow pits and ditches have been developed. According to Centre for Integrated Rural Development in Asia and the Pacific (CIRDAP), study in 1987 on the impact of flood control in three Flood Control Drainage and Irrigation (FCDI) projects it was found that flood protection improved conditions for expanding and intensifying pond fish culture. 


\section{OBJECTIVE}

The objective of this study was to conduct a comparative study on the closed water fishery resources between inside and outside the embankment of Meghna Dhonagoda Irrigation Project (MDIP).

\section{MATERIAL AND METHODS}

Closed water (ponds and borrow pits) survey was carried out in both inside and outside of the embankment. At first $10 \%$, out of 241 villages, was selected randomly from inside the embankment. Then, all the ponds and borrow pits of the selected villages were surveyed. The selected villages (24) covered nine unions inside the project area. Thus, 378 ponds and 22 borrow pits were surveyed by using the pre-tested questionnaires which include questions like fish production, types of fish species, types of culture, ownership, position of pond owners, methods of fish culture, problems of fish culture, etc. Similarly, the same methods were applied in outside the embankment and five villages out of 46 were selected randomly. So, the selected $10 \%$ villages include 43 ponds and six borrow pits, which were surveyed, and the data as in inside were collected. The surveys were conducted for the period of two years (2003-2004 and 2004-2005).

\section{RESULTS AND DISCUSSION}

In Meghna Dhonagoda Irrigation Project (MDIP) area, closed water fisheries based on culture fisheries in the ponds and borrow-pits have been developed after construction of embankment. Particularly, the development of culture fisheries was noticed in the ponds and borrow-pits. The people of MDIP area started fish culture in ponds and borrow pits in both inside and outside the embankment. The findings were recorded in terms of flooding, type of water body, ownership, type of culture, method of culture, problems of fish culture regarding the production of culture fishery resources both inside and outside of MDIP in Matlab North area.

Over flooding of closed water: During 2003-2004, it was observed that only six percent ponds and borrow-pits were over flooded inside the embankment causing rain water congestion which was seven percent in 2004-2005. On the other hand, $46.94 \%$ and $51.02 \%$ in 2003-2004 and 2004-2005, respectively outside the embankment were subject to over-flooding during monsoon.

It was observed that $6-7 \%$ ponds and borrow pits were over flooded inside due to rain water congestion where $47-51 \%$ were over flooded outside the embankment during monsoon. Although no substantial work was done like 
inside and outside areas of the embankment, but Kaiya et al. (1987) reported that $53.3 \%$ ponds were found to become flooded every year, which is almost similar with the present findings obtained outside the embankment.

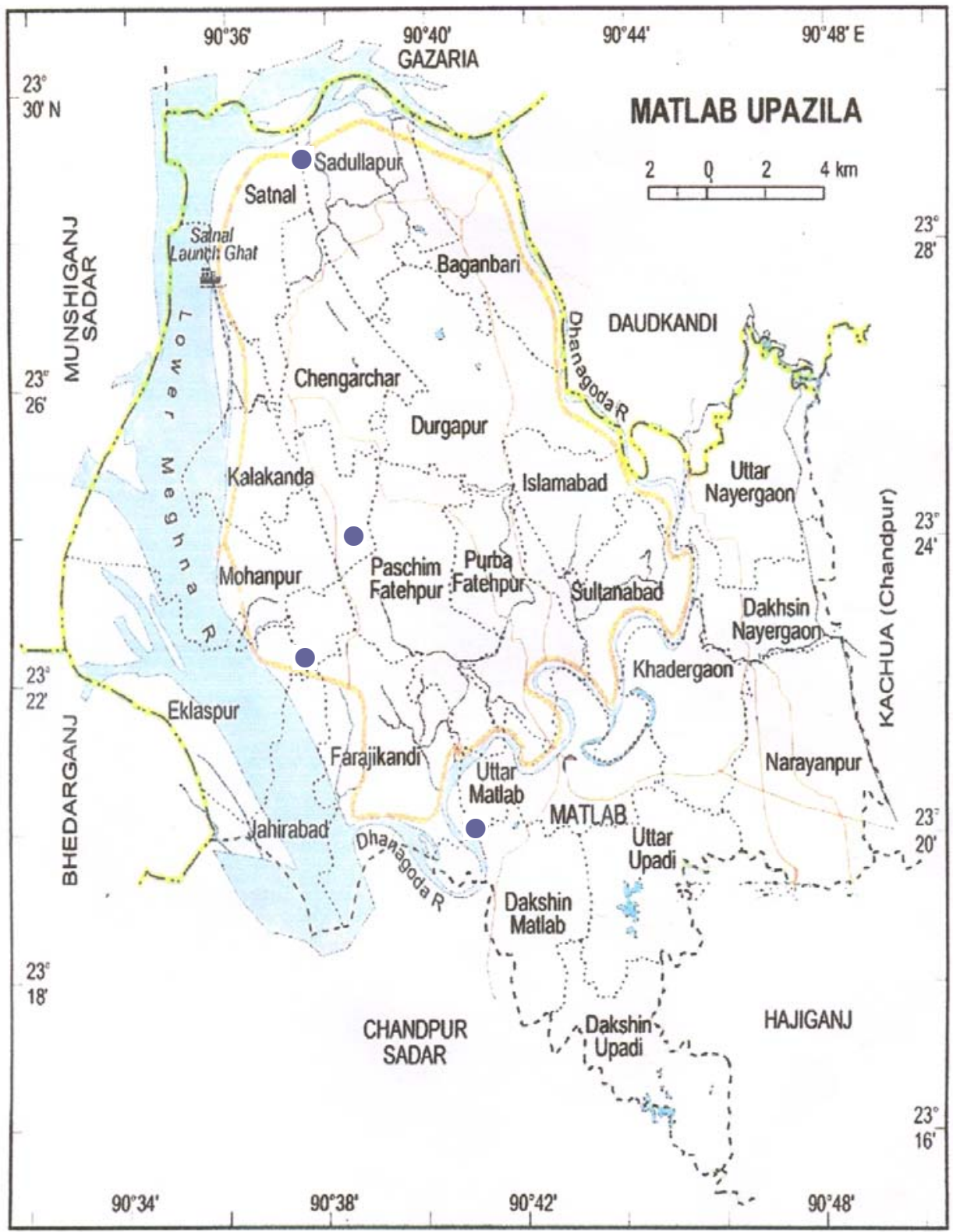

Legend : ............ Ėmbankment Kivers (Meghna \& Dhonagoda)

- Udamdi pump house, - Kalipur pump house, Eklashpur booster pump house

- Dubgi booster pump house

Fig.1. Map of the Meghna Dhonagoda Irrigation Project, Matlab North, Chandpur. 
Type of water body: Among the surveyed ponds and borrow-pits $17.75 \%$ was seasonal and $82.25 \%$ was perennial inside the embankment of MDIP in both years of study. Whereas, $20.41 \%$ was seasonal and $79.59 \%$ was perennial outside the embankment [Fig.2a-b).

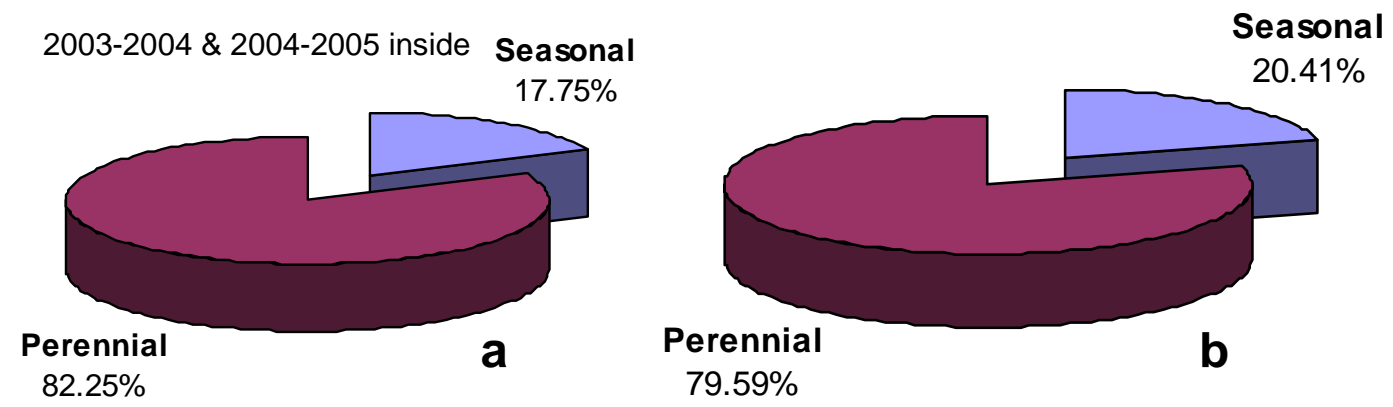

Fig. 2a-b. Contribution of ponds and borrow-pits on the basis of type of water body both inside and outside of MDIP in 2003-2004 and 2004-2005.

Ownership: On the basis of ownership it was observed that $24 \%$ was single ownership inside and $30.61 \%$ outside the embankment in two years of study. But, $47.5 \%$ was joint ownership inside and 38.78\% outside in 2003-2004. Almost the same figure $46.5 \%$ inside and $36.74 \%$ outside were found in 20042005. In case of lease ownership, $28.5 \%$ and $29.5 \%$ inside, $30.61 \%$ and $32.65 \%$ outside in the years 2003-2004 and 2004-2005, respectively. These results are presented in Fig. 3.

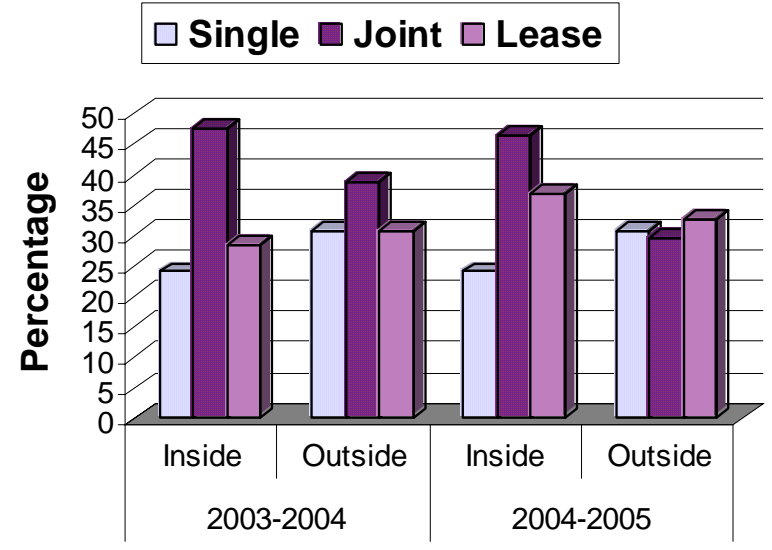

Area of study and period

Fig. 3. Contribution of ponds and borrow-pits on the basis of ownership both inside \& outside of MDIP in 2003-2004 and 2004-2005. 
Envisaging ownership it was found that the single ownership (24\%) inside was less than outside $(30.61 \%)$ the embankment, where the joint ownership $(47.5 \%)$ inside was higher than outside (36.74\%). On the other hand, lease ownership (28.5\%) inside was almost the same as outside $(30.61 \%)$. Both inside and outside of the embankment, joint ownership was higher than other ownerships and it was also the problem for fish culture. Although no exact work was done like inside and outside the embankment however Kaiya et al. (1987) found that the ownership of ponds of Mirzapur Upazila under Tangail district was $42.1 \%$ single ownership and $40.1 \%$ joint ownership. He also noticed that multiple ownership was an important problem, which is agreed with this research. BRAC (1982) also expressed the same opinion.

Type of culture: Two types of ponds- cultured and culturable were found both inside and outside of the embankment. But, no borrow pits was found culturable. $94.25 \%$ ponds and borrow pits were cultured inside the embankment in 2003-2004 and almost the same (95\%) inside in 2004-2005. On the other hand, 5.75\% and 5\% were culturable in 2003- 2004 and 2004-2005 respectively. In outside region, $69.39 \%$ and $73.47 \%$ were cultured, $30.61 \%$ and $26.53 \%$ were culturable in both the years of study (Fig. $4 a-d)$.
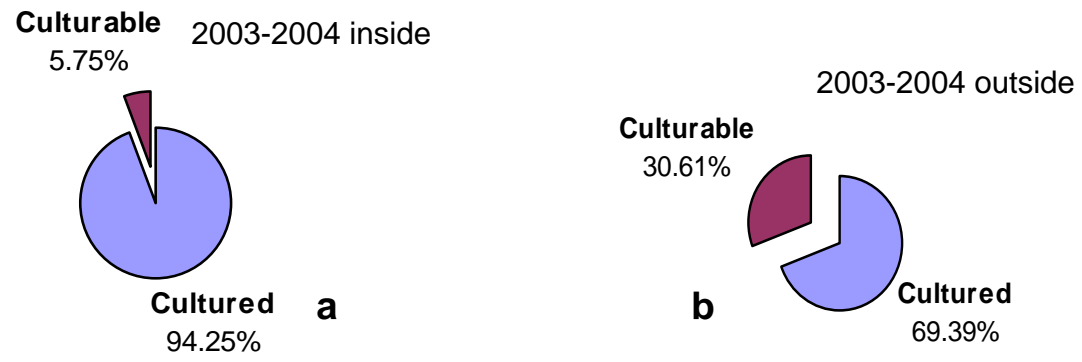

2004-2005 inside 2004-2005 outside
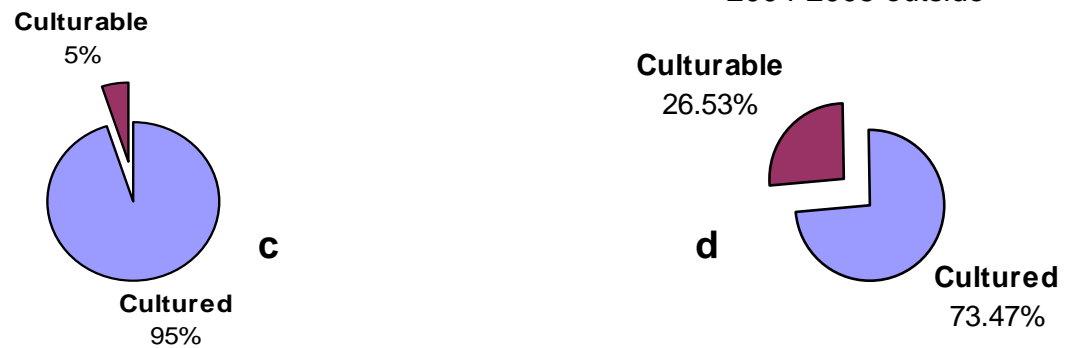

Fig. 4a-d. Contribution of ponds and borrow-pits on the basis of type of culture both inside and outside of MDIP in 2003-2004 and 2004-2005 
It clearly indicates that the opportunities of fish culture in ponds and borrow pits were very high and occurred for the construction of embankment. According to SPARRSO (1984) 43\% are cultured, 30\% culturable and $27 \%$ derelict. But, the present findings inside the embankment indicate that the percentage of cultured ponds and borrow pits were higher than the findings of SPARRSO (1984). On the other hand, in case of the outside region of MDIP in Matlab North, although the number of cultured ponds and borrow pits were higher, but culturable ponds were the same as SPARRSO (1984). But no derelict ponds were found both inside and outside the embankment. The cultured ponds identified by ICLARM (1994) were managed in various ways with: Regular stocking with occasional feeding and fertilizing; Regular stocking without feeding and fertilizing; Irregular stocking without feeding and fertilizing. These were also followed in the cultured ponds and borrow pits in MDIP area.

Method of culture: Extensive and improved extensive methods of fish culture were commonly followed in both inside and outside regions. In inside, extensive $(48.27 \%)$ and improved extensive (47.75\%) were observed in 2003-2004 and almost the same result was found $(46.58 \% \& 49.47 \%$, respectively) in 20042005. On the other hand, in outside region, $61.76 \% \& 58.33 \%$ were extensive method of fish culture and $38.24 \% \& 41.67 \%$ improved extensive in $2003-2004$ and 2004-2005, respectively. Only 3.98\% and 3.95\% were under Semi-intensive method of culture inside the embankment in both the years of study, but not found outside (Fig.5).

\section{$\square$ Semi Intensive $\square$ Improve Extensive $\square$ Extensive}

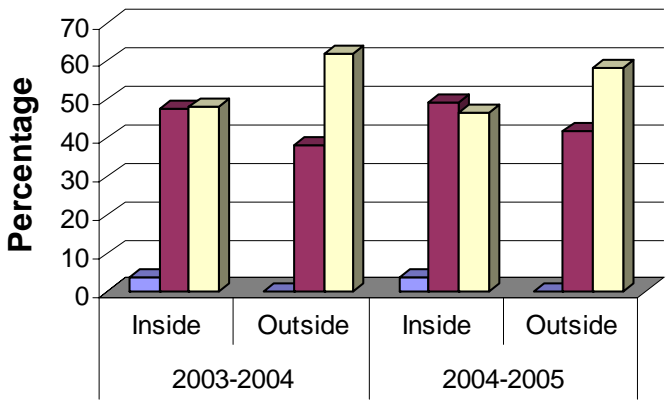

Area of study and period

Fig 5. Contribution of ponds and borrow-pits on the basis of method of culture both inside and outside of MDIP in 2003-2004 and 2004-2005

The result showed that $48.27 \%$ was extensive, $47.75 \%$ improved extensive and $3.98 \%$ semi-intensive in inside, whereas, $61.76 \%$ was extensive, $38.24 \%$ improved extensive and no semi-intensive method was followed in outside. It is 
evident that culture technology has been developed more inside than outside the embankment.

Problems of fish culture in closed water: The views of 400 ponds and borrowpit owners of the region inside and 49 owners of the region outside the embankment regarding the problems associated with fish culture in their ponds and borrow pits are presented in Fig.6. The major problem was lack of training $(38 \%$ and $37 \%)$ in inside and also the same $(40.82 \%$ and $38.78 \%)$ in outside region in both years. The second major problem was the lack of fund $(33.75 \%$ and $35 \%)$ in inside, but the problem by inundation in monsoon $(28.57 \%$ and $26.53 \%$ ) was for outside owners in 2003-2004 and 2004-2005, respectively followed by the lack of unity $(18.75 \%$ and $19.25 \%)$ inside and $(12.24 \%$ and $14.29 \%)$ outside the embankment. The problem of the lack of fund $(10.21 \%$ and $12.24 \%$ ) in outside was almost the same as the lack of unity outside in both years. The minor problem (1.25\%) was inundation in monsoon in inside in both years and the second minor was non-availability of fry $(4.5 \% \& 4 \%)$ in inside and $4.08 \%$ in outside in 2003-2004 \& 2004-2005, respectively and prevention of disease $(3.75 \% \& 3.5 \%)$ in inside and $4.08 \%$ in outside region in both years which were almost the same as second minor problem for fish culture.

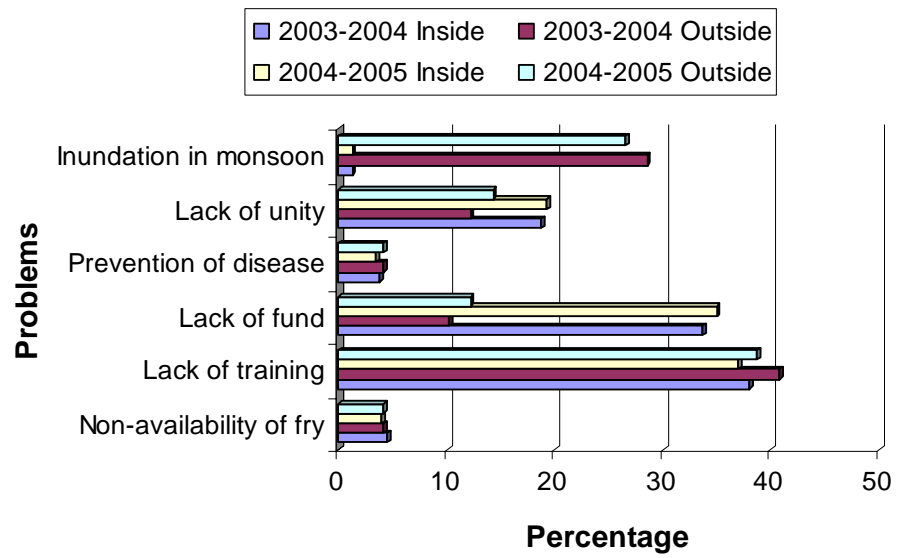

Fig. 6. Problems of fish culture in ponds and borrow-pits both inside and outside of MDIP in 20032004 and 2004-2005

Kaiya et al. (1987) noticed that multiple ownership is an important problem, which is agreed with this research. BRAC (1982) also expressed the same opinion. Karim (1978), Gill and Motahar (1982) and Ali et al. (1982) identified the same as a major problem for fish culture. The present study showed the major problem was the lack of training both inside and outside the embankment which is not similar to their findings. 


\section{Production of closed water (ponds and borrow-pits) on the basis of different categories}

(a) Production on the basis of ownership: Three categories of ownerships were found among the ponds and borrow pits owners both inside and outside the embankment. These were the single, joint and lease. On the basis of ownership of closed water (both ponds and borrow pits), the highest production (2536.42 $\mathrm{kg} / \mathrm{ha}$ and $2550.53 \mathrm{~kg} / \mathrm{ha}$ ) observed in single ownership in the inside in both the years of study. The second highest $(2464.73 \mathrm{~kg} / \mathrm{ha}$ and $2529.75 \mathrm{~kg} / \mathrm{ha})$ in lease ponds and borrow pits and the lowest production $(2199.83 \mathrm{~kg} / \mathrm{ha}$ and $2262.48 \mathrm{~kg} / \mathrm{ha}$ ) was in joint ownership ponds in the inside region in 2003-2004 and 2004-2005. In case of outsider ponds and borrow pits, the highest production was in lease ownership both the years of study $(2110.66 \mathrm{~kg} / \mathrm{ha}$ and $2167.92 \mathrm{~kg} / \mathrm{ha})$, followed by single ownership $(1784.18 \mathrm{~kg} / \mathrm{ha}$ and 1926.55 $\mathrm{kg} / \mathrm{ha})$ and the lowest production was in joint ownership $(1599.30 \mathrm{~kg} / \mathrm{ha}$ and $1703.39 \mathrm{~kg} / \mathrm{ha}$ ) in 2003-2004 and 2004-2005, respectively. The production data were given in Fig.7. It was clear that in all types of water bodies, on the basis of ownership, the production was slightly higher in 2004-2005 than in 2003-2004. The production was also higher in the inside region in all cases than that of the outside region of the embankment both in 2003-2004 and 2004-2005.

The result indicates that the single owner ponds and lease owner ponds are to be managed more or less scientifically than joint owner ponds.

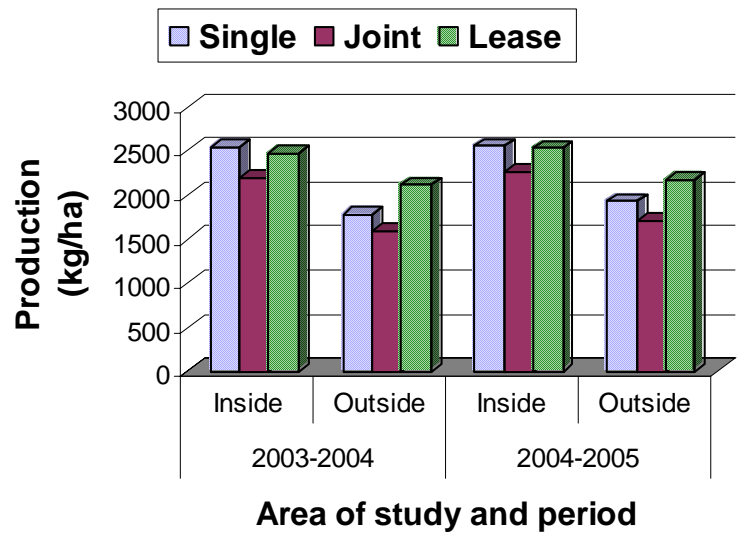

Fig. 7. Production of fishes in closed water (ponds and borrow-pits) on the basis ownership both inside and outside of MDIP in 2003-2004 and 2004-2005

(b) Production on the basis of type of water body: In two years of study, both inside and outside regions, the production was higher in perennial water body (ponds and borrow-pits) than in seasonal water body. In the inside region, the production of fishes was $2415.77 \mathrm{~kg} / \mathrm{ha}$ and $2479.81 \mathrm{~kg} /$ ha in perennial water 
body (ponds and borrow-pits) in 2003-2004 and 2004-2005, whereas 1638.98 $\mathrm{kg} / \mathrm{ha}$ and $1664.50 \mathrm{~kg} / \mathrm{ha}$ in seasonal water body. On the other hand, in the outside region, the production was $2011.67 \mathrm{~kg} / \mathrm{ha}$ and $2098.67 \mathrm{~kg} / \mathrm{ha}$ in perennial water body but $1409.76 \mathrm{~kg} / \mathrm{ha}$ and $1578.05 \mathrm{~kg} / \mathrm{ha}$ in seasonal water body, in two years of study. It was evident that both the inside and outside of the embankment of MDIP, the production of fishes was higher in the perennial water body than the seasonal water body. The results are shown in Fig.8. In both the inside and outside regions, it was observed that the production was a little bit increased chronologically in 2004-2005 in both types of water body than the previous year of the study.

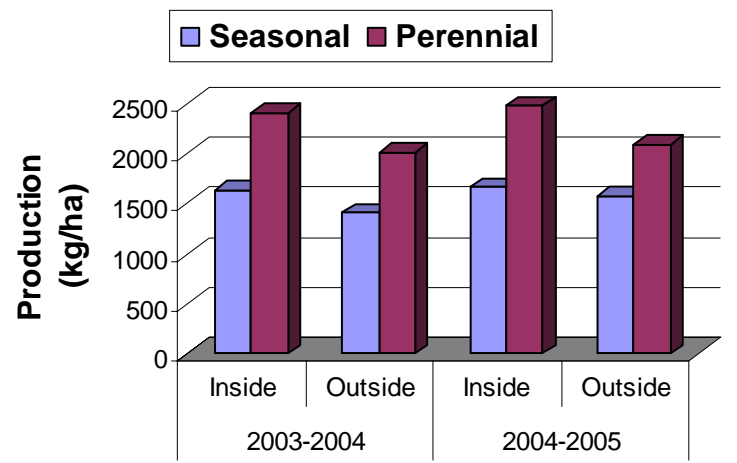

Area of study and period

Fig. 8. Production of fishes in closed water (ponds and borrow-pits) on the basis of type of water body both inside and outside of MDIP in 2003-2004 and 2004-2005

(c) Production on the basis of type of culture: The production of fishes was higher in cultured ponds and borrow-pits in both inside and outside regions than that of culturable. In 2003-2004 and 2004-2005, the production in cultured ponds and borrow pits was $2440.65 \mathrm{~kg} / \mathrm{ha}$ and $2494.70 \mathrm{~kg} / \mathrm{ha}$ in the inside and $2076.93 \mathrm{~kg} / \mathrm{ha}$ and $2140.22 \mathrm{~kg} / \mathrm{ha}$ in the outside region. But, in case of culturable ponds, the production was lower $(641.95 \mathrm{~kg} / \mathrm{ha}$ and $561.07 \mathrm{~kg} / \mathrm{ha})$ in the inside region than in the outside region $(1274.89 \mathrm{~kg} / \mathrm{ha}$ and 1244.05 $\mathrm{kg} / \mathrm{ha}$ ) in 2003-2004 and 2004-2005, respectively (Fig.9). It was evident that the production of culturable ponds in the outside of the embankment was almost double than that of the inside of the embankment of MDIP. In case of culturable ponds, there was an exceptional; the production was higher in 2003-2004 than in 2004-2005 both the inside and outside regions. It may be noted that no borrow pits were found as culturable in both the inside and outside the embankment of MDIP.

In culturable ponds in the inside, the production was $641.95 \mathrm{~kg} / \mathrm{ha}$ and $561.07 \mathrm{~kg} / \mathrm{ha}$ in 2003-2004 and 2004-2005, respectively which is inconformity 
with the findings of MPO (1984). According to MPO (1984), the production in this type of ponds usually does not exceed $500 \mathrm{~kg}$ ha/yr. But, the production of the same type of ponds in the outside region of MDIP was at least 1274.89 $\mathrm{kg} / \mathrm{ha}$, which is more than double of the findings of MPO (1984).

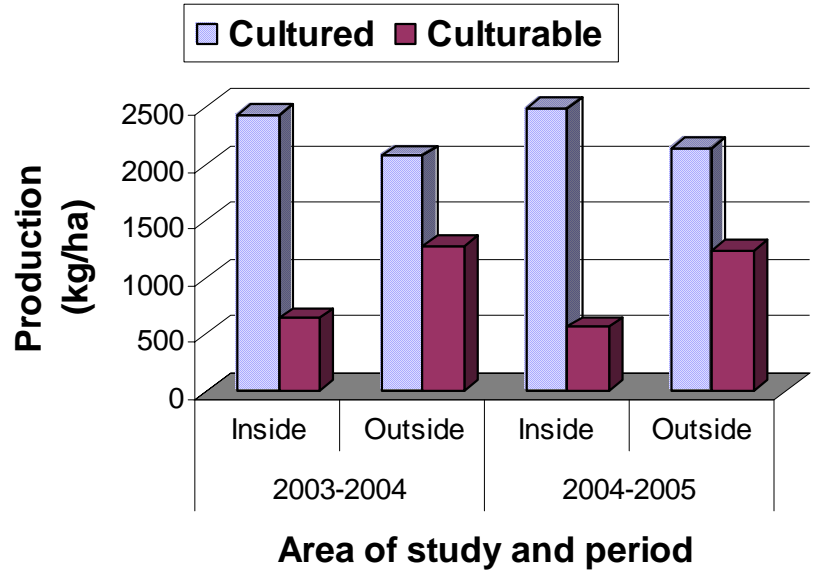

Fig. 9. Production of fishes in closed water (ponds and borrow-pits) on the basis type of culture both the inside and outside of MDIP in 2003-2004 and 2004-2005.

(d) Production based on the method of culture: It was observed that three types of methods of fish culture were practiced to produce fish in the ponds and borrow-pits during two years of study, such as extensive, improved-extensive and semi-intensive cultures. Generally in the borrow-pits, semi-intensive culture was not found. The semi-intensive culture was practiced in the ponds of the inside region only and showed the highest production $(4574.42 \mathrm{~kg} / \mathrm{ha}$ and $4646.51 \mathrm{~kg} / \mathrm{ha}$ ), followed by $2870.30 \mathrm{~kg} / \mathrm{ha}$ and $2847.87 \mathrm{~kg} / \mathrm{ha}$ by the improved-extensive culture and the lowest $1886.65 \mathrm{~kg} / \mathrm{ha}$ and $1919.53 \mathrm{~kg} / \mathrm{ha}$ by the extensive culture in 2003-2004 and 2004-2005, respectively. Similarly, the same tendency was observed in the ponds and borrow pits of the outside region by the improved-extensive and extensive cultures in both the years of study $(2430.03 \mathrm{~kg} / \mathrm{ha}$ and $2385.16 \mathrm{~kg} / \mathrm{ha})$ and $(1754.89 \mathrm{~kg} / \mathrm{ha}$ and 1888.24 $\mathrm{kg} / \mathrm{ha}$ ). In all types of culture methods, the production was higher in the inside region than that of the outside in both the years of study (Fig. 10).

The highest production (4574.42 kg/ha and $4646.51 \mathrm{~kg} / \mathrm{ha}$ ) was observed by the semi-intensive method and the lowest production $(1886.65 \mathrm{~kg} / \mathrm{ha}$ and $1919.53 \mathrm{~kg} / \mathrm{ha}$ ) was observed by the extensive method in two years of study in the inside, respectively, which is very high and not in conformity with the findings of Islam and Dewan (1986), who reported that the production of fish by the extensive culture was $500 \mathrm{~kg} / \mathrm{ha} / \mathrm{yr}$ and by the semi-intensive was 2725 
$\mathrm{kg} / \mathrm{ha} / \mathrm{yr}$. From the present findings, it may be mentioned that the fish culture practice has been developed scientifically and production increased gradually in MDIP area. Furthermore, Quddus et al. (2000) found that per hectare yield of the extensive, improved extensive and semi-intensive categories of culture were $1.3,2.12$ and 4.0 metric tons, respectively which support the present findings of yield in the extensive culture ponds (1.89 mt/ha), improved extensive culture ponds $(2.87 \mathrm{mt} / \mathrm{ha})$ and semi-intensive culture ponds $(4.57 \mathrm{mt} / \mathrm{ha})$ in 20032004 in inside of MDIP. According to Tripathi (1990), the yield rates of 2000 $\mathrm{kg} / \mathrm{ha} / \mathrm{yr}$ under the extensive and $5000-7000 \mathrm{~kg} / \mathrm{ha} / \mathrm{yr}$ under the semiintensive systems are now easily possible which strongly supports the present findings.

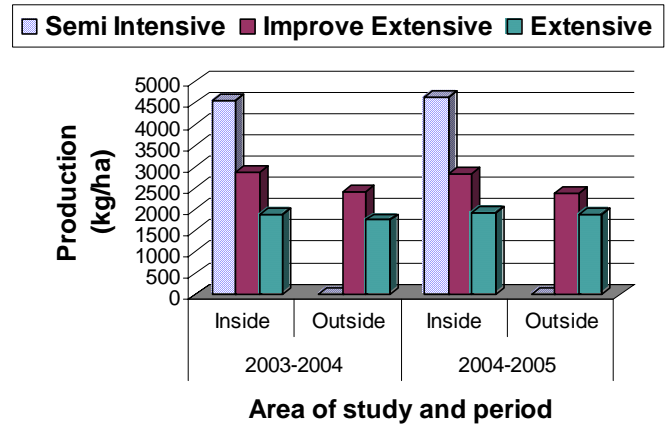

Fig. 10. Production of fishes in closed water (ponds and borrow-pits) on the basis method of culture both inside and outside of MDIP in 2003-2004 and 2004-2005

(e) Average production of fishes in closed water (ponds and borrow-pits): The average production of fishes in closed water (ponds and borrow pits) in the inside and outside of the regions of the embankment of MDIP was slightly higher in 2004-2005 than 2003-2004 (Fig.11). The average production was 2374.39 $\mathrm{kg} / \mathrm{ha}$ in inside, whereas, $1984.32 \mathrm{~kg} / \mathrm{ha}$ in the outside in 2003-2004. On the other hand, the average production was $2436.37 \mathrm{~kg} / \mathrm{ha}$ in the inside and $2075.01 \mathrm{~kg} / \mathrm{ha}$ in the outside region in 2004-2005.

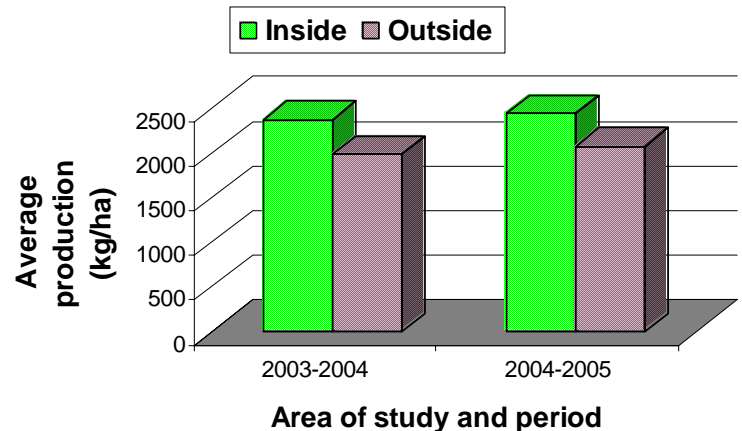

Fig. 11. Average production of fishes in ponds and borrow-pits both inside and outside of MDIP in 2003-2004 and 2004-2005 
The average production was found $2374.39 \mathrm{~kg} / \mathrm{ha}$ in $2003-2004$ in the inside was slightly lower than the national average production of ponds $(2609$ $\mathrm{kg} / \mathrm{ha}$ ) in $2003-2004$ and the average production found $2436.37 \mathrm{~kg} / \mathrm{ha}$ in $2004-$ 2005 in the inside region is almost similar to the national average production of ponds $(2482 \mathrm{~kg} / \mathrm{ha})$ in 2004-2005. In contrast, the average production was found $1984.32 \mathrm{~kg} / \mathrm{ha}$ and $2075.01 \mathrm{~kg} / \mathrm{ha}$ in 2003-2004 and 2004-2005, respectively in the outside region is less than that of national average production in the aforementioned years (BFRSS 2004 and 2005). ADB (2005) reported that culture fisheries was developed in the MDIP area due to the small scale fisheries and aquaculture development within the irrigation command areas through extension services, organizational and management development support, and credit inputs to initiate small scale fresh water aquaculture, primarily in small ponds, for the poor. FAP-12(1992b) and Ali (1994) reported that average pond production in the MDIP area was $1400 \mathrm{~kg} / \mathrm{ha}$ and calculated that gained 400 $\mathrm{kg} / \mathrm{ha}$. So, the present average production indicates that culture fisheries production the increased in the MDIP area gradually.

The data obtained by different types of surveys from both the inside and outside of the embankment of MDIP were processed and analyzed with the help of computer software, i.e. Microsoft Excel, SPSS etc. SPSS for Windows version 10.0 was used to process the collected data. Both pair and independent t-test test were performed to know the significant difference between the data of the inside and outside regions of MDIP. It was observed that there is a difference between the average production of fish ( $\mathrm{kg} / \mathrm{ha}$ ) of the inside and outside closed water bodies of MDIP in both the years of study. When the difference is statistically tested it is observed that the difference in the closed water body (ponds and borrow-pits) fish production between the two zones during 20032004 and 2004-2005 was significant at 0.001 level ( $p=0.001)$.

Acknowledgements: This paper is a part of Ph.D. research work of the first author. The authors gratefully acknowledge the Ministry of Fisheries and Livestock for granting deputation for the Ph. D. research work, and DFID and British Council for funding.

\section{CONCLUSION}

The culture fishery has been developed in the inside of the MDIP project area after the construction of Flood Control, Drainage and Irrigation (FCDI) Project works. The average production of fishes in the closed water (ponds and borrow pits) was higher in the inside than the outside of the regions in both 2003-2004 and 2004-2005. The significant difference $(\mathrm{p}<0.001)$ was found between the inside and the outside of the MDIP area. Overall production of the closed water 
increased in the inside region, however, the production of culturable ponds was higher in the outside region.

\section{LITERATURE CITED}

ADB. 2005. An Evaluation of Small-scale Freshwater Rural Aquaculture Development for Poverty Reduction. Operations Evaluation Department, Asian Development Bank, 2005. pp. 164.

AHMAD, N. 1952. Fisheries of East Pakistan. Econ. Obs. Karachi. Vol. VI (23/24): 1-11.

ALI, M.H., AKBAR, M.A. and RAHMAN, H.M. 1982. Utilization of fish ponds in Mymensingh district. Bangladesh J. Agril. Econ. 5: 103-114.

ALI, M.Y. 1994. Report on the study of the fisheries situation under the socio-environmental assessment of Meghna-Dhonagoda Irrigation Project. Bangladesh Centre for Advanced Studies (BCAS) and Bangladesh Engineering and Technological Services (BETS), Dhaka, August, 1994. pp. 51 .

BBS. 2001. Report of Household Income and Expenditure Survey 2001. Bangladesh Bureau of Statistics, Dhaka.

BFRSS.1986. Manual of Catch Assessment Survey (Revised). DOF. MOFL. Dhaka:122 p.

BFRSS. 2004. Fishery Statistical Yearbook of Bangladesh. DOF., MOFL. p. 41.

BFRSS. 2005. Fishery Statistical Yearbook of Bangladesh. DOF., MOFL. p.42.

BRAC. 1982. Inventory of Present Status of Fisheries Research in Bangladesh. Fisheries Technical Working Group, BRAC, Dhaka.

CIRDAP. 1987. The impact of FCD/I projects in Bangladesh: Benchmark Survey Initiation of a monitoring and evaluation system (MES). Final Report. FRC Entry No. 3185.

DOF. 2005. Brochure on Fish Fortnight. National Fish Fortnight-2005. Department of Fisheries, Ministry of Fisheries and Livestock, Dhaka, Bangladesh.

FAP-12.1992. Project impact evaluation of Meghna-Dhonagoda Irrigation Project. FCD/I Agricultural Study FAP. Hunting Technical Services Ltd, February 1992. pp.175.

FAO.1987. Yearbook. Fisheries Statistics. Vol. 64 \& 65.

GILL, G.J. and MOTAHAR, H. A. 1982. Social factors affecting prospects of intensified fish farming in Bangladesh. Bangladesh J. Agril. Econ. 5: 1-24.

HAQUE, K.A. 1980. Development and management of aquaculture. Paper presented as the saminar on Strategy for Aquaculture Development in Bangladesh, Bangladesh Agricultural University, Mymensingh, 4-5 Oct., 1980.

ICLARM. 1994. Baseline pond survey. Final report. MAEP, Mymensingh. pp.28.

ISLAM, M.S. and DEWAN, S. 1986. Resource use and economic return in pond fish culture. Bangladesh J. Agril. Econ. 9(2): 141-150.

KAIYA, M.K.U., MOLLAH, M.F.A. and ISLAM, M.S. 1987. Survey of pond fishery resources in Mirzapur upazila under Tangail district. Bangladesh J. Fish. 10(1): 37-43.

KARIM, M. 1978. Status and Potential of Bangladesh Fisheries. Dacca. Ministry of Fisheries and Livestock, GOB. 125 pp.

KHAN, M.S., QUDDUS, M.A. and ISLAM, M.A. 1991. A study of pond fishery resources in Trisal upazila. Bangladesh J. Ext. Edu. 6(1 \& 2): 55-64.

MPO. 1984. Master Plan Organization. Water development and flood control, National Water Plan Project, Second Interim Report: VII Fishes. Dhaka, Ministry of Irrigation.

QUDDUS, M.A., RAHMAN, M.S. and MONIRUZZAMAN, M. 2000. Socio-economic conditions of the pond owners of Demra, Dhaka. Bangladesh J. Fish. Res. 4(2): 2000: 203-207. 
QURESHI, M.R. 1951. Fish and nutrition. Pakistan Medical Journal. July : 1-4.

RAHMAN, M.M. 1986. Small-scale fisheries in Bangladesh: Some socio-economic problems and issues. Bangladesh J. Agril. Econ. 9(2): 97-110.

RUBBI, S.F., MUSLEMUDDIN, M. and WAHAB, M.A. 1978. The present status of fish technology and inspection in Bangladesh. Paper presented in FAO/DANIDA Workshop of fish technology. Colombo, Srilanka.

SPARRSO. 1984. Report on FAO/ UNDP Project in Bangladesh. Contract No. DP/ BGD/79/ 015-2/FI (Fisheries Resources Survey System). Dhaka. xiii + 120 pp.

TRIPATHI, S.D. 1990. Recent Advances in Freshwater Aquaculture. In: Impacts of Environment on Animals and Aquaculture (Eds. G. K. Manna and B. B. Jana), 1990: 69-77.

(Manuscript received on February 25, 2010; revised on September 7, 2011) 